\title{
Experimental Constraints on the Formation of Pegmatite-forming Melts by Anatexis of Amphibolite: A Case Study from Evje-Iveland, Norway
}

\author{
AUSTIN M GION ${ }^{1,2,3}$, PHILIP M PICCOLI ${ }^{1}$, YINGWEI FEI ${ }^{2}$, \\ PHILIP A CANDELA ${ }^{1}$ AND RICHARD D ASH ${ }^{1}$ \\ ${ }^{1}$ University of Maryland \\ ${ }^{2}$ Earth and Planets Laboratory, Carnegie Institution for Science \\ ${ }^{3}$ Univ. Orléans, CNRS, BRGM, ISTO \\ Presenting Author: austin.gion@cnrs-orleans.fr
}

The Evje-Iveland pegmatite field in Norway is host to rare element pegmatites that are known for their scandium mineralization. The petrogenesis of these pegmatites and the origin of the scandium has been debated for nearly a century beginning with the observations and interpretations of Victor Goldschmidt in 1934. Goldschmidt ${ }^{[1]}$ hypothesized that the scandium was scavenged from the surrounding amphibolite by the pegmatite-forming melt. Subsequent, hypotheses for the origin of the scandium-rich melt and scandium have included magmatic differentiation (wherein scandium was concentrated by magmatic processes) and partial melting of the host amphibolite. In order to evaluate the hypothesis that the pegmatite-forming melt was generated by anatexis of the host amphibolitem partial melting experiments on the host amphibolite were performed

Experiments were carried out in a piston-cylinder apparatus at temperatures ranging from $700^{\circ}$ to $1064^{\circ} \mathrm{C}$ and pressures between 400 and $550 \mathrm{MPa}$. The vapor-absent solidus of the host amphibolite is approximately $900^{\circ} \mathrm{C}$ at $500 \mathrm{MPa}$, which is consistent with previous experimental studies. Partial melting $(<40 \%)$ of the host amphibolite produces aluminum- and sodium-rich felsic glasses with $\mathrm{Al}_{2} \mathrm{O}_{3}$ and $\mathrm{Na}_{2} \mathrm{O}$ concentrations of up to $25 \mathrm{wt} \%$ and $9 \mathrm{wt} \%$ on an anhydrous basis, respectively. However, the $\mathrm{SiO}_{2}$ concentration of these glasses are between 49 and $72 \mathrm{wt} \%$ on an anhydrous basis and are not as felsic as the Evje-Iveland pegmatites, which reach up to $74 \mathrm{wt} \% \mathrm{SiO}_{2}$. Additionally, these glasses are poor in scandium $(<50 \mathrm{ppm})$, as well as REEs and many other trace elements. Further, these glasses have REE patterns that are dissimilar to the Evje-Iveland pegmatites but similar to leucosomes in vein-type migmatites formed at low pressures. The results of the experiments performed here are inconsistent with the hypothesis that the Evje-Iveland pegmatites formed from direct anatexis of the host amphibolite. After excluding an anatectic origin we propose that the Evje-Iveland pegmatites were formed by the partial melting and magmatic differentiation of a scandium-rich mafic to ultramafic complex.

[1] Goldschmidt, V.M. (1934) Drei Vorträge über Geochemie. Geologiska Föreningen i Stockholm Förhandlingar 56, 385-427. 